\title{
Authentication of "Chirayat" complex by high resolution seed morphology
}

\author{
Bharati Rajput*, Vinaya Ghate \\ Plant Science Divison, Agharkar Research Institute, Pune 411004, India.
}

\begin{tabular}{|c|c|}
\hline ARTICLE INFO & ABSTRACT \\
\hline $\begin{array}{l}\text { Article history: } \\
\text { Received on: } 13 / 11 / 2014 \\
\text { Revised on: } 23 / 11 / 2014 \\
\text { Accepted on: } 12 / 12 / 2014 \\
\text { Available online: } 27 / 12 / 2014\end{array}$ & $\begin{array}{l}\text { Twelve different species belonging to Andrographis, Enicostema, Exacum, Indoneesiella, Peristrophe and } \\
\text { Swertia are used as crude drugs under the common name Chirayat depending on region specific availability and } \\
\text { diverse traditions all over the country. The crude drug is available in the local market in the form of whole plant } \\
\text { consisting of stems, twigs with flowers and fruits. Microscopic characterization of powder sample revealed the } \\
\text { presence of seeds with beautiful surface ornamentation. The observations indicated potential for using seed } \\
\text { morphology as identification character. The seed surface morphology of twelve species was studied using light } \\
\text { microscope (LM) and scanning electron microscope (SEM). The studies revealed species specific variations with }\end{array}$ \\
\hline $\begin{array}{l}\text { Key words: Chirayat species, } \\
\text { seed morphology, surface } \\
\text { structure. }\end{array}$ & $\begin{array}{l}\text { reference to shape, size, colour and particularly surface. Authentication keys for Chirayat complex based on } \\
\text { variations have been proposed. }\end{array}$ \\
\hline
\end{tabular}

\section{INTRODUCTION}

The crude drug, 'Chirayat' is available in the market in the form of whole plant sample which contains twigs with flowers and fruits. These broken samples particularly flowers, fruits and seeds provide clue for identification of sample at species level. The seed samples of twelve different species belonging to Chirayat complex, therefore, were studied using SEM which provided characters for identification of specific species. Scanning Electron Microscopy of seed surface has been used for classification of certain species, genera or even families and for resolving the ambiguities within and between species [17]. Authentication of crude drugs has become mandatory at various levels.

For this purpose, pharmacognostic tools including exo-morphy, anatomy; phyto-chemical tests are being applied. Application of SEM as additional tool for authentication of crude drugs can be effectively used for whole plant drugs and fruit-seed drug samples available in market. No such attempts in Chirayat complex have been made so far. In the view of unavailability of methods for authenticating Chirayat complex and utility of SEM as tool for authentication of crude drugs, SEM was used to study the seed morphologies of twelve different species belonging to Chirayat complex. In the present study, the species specific variations with in shape, size, color and surface were used to propose the authentication keys.

* Corresponding Author

Email-bharti_rati@yahoo.co.in

\section{MATERIALS AND METHODS}

Twelve species belonging to Chirayat complex were collected from the wild habitats. Species were identified and nomenclature was updated using Garg, 1987 [8] and Singh et al. [9]. Seeds were obtained from matured fruits after their natural dehiscence and studied for macro characters like shape, size and colour using stereo zoom binocular.

For SEM studies seed samples were cleaned and dehydrated through a graduated ethanol series and minimum four seeds per species were mounted on aluminium stubs, sputter coated with gold on Polaron SC 7640 sputter coater. They were scanned with Cambridge Instruments S-120 Scanning Electron Microscope for surface structures.

\section{RESULTS AND DISCUSSION}

Twelve different species are currently being used under the common name Chirayat depending on region specific availability and diverse traditions all over India. Grouping them under common name may be because of similarities in morphology for example, quadrangular stem in all the species and leaves with 3 distinct veins except for Enicostemma. Many a times it is difficult to identify species at collector's level because of similarity in gross morphology, e.g. S.chirayata and S.lurida are almost identical in general appearance. On the other hand it is very essential to confirm identity at user's level, i.e. pharmacy companies in order to keep quality and efficacy of drug. Recently it has become mandatory to authenticate the materials from recognized laboratories. 
In case of chirayat complex, seed studies may provide additional and easy parameter for authentication of proper species. In this study, following observations for twelve species under study were made

\subsection{Observations}

\subsubsection{Swertia chirayita (Roxb. ex Fleming) Karsten.}

Seed ovate, yellowish-brown, $0.24 \times 0.14 \mathrm{~mm}$ with shallowly sunken sides. Outer testa reticulate; cells polygonal, oriented irregularly, anticlinal walls curved, middle lamella conspicuous, lumen smooth and shallowly concave (Fig.1a).

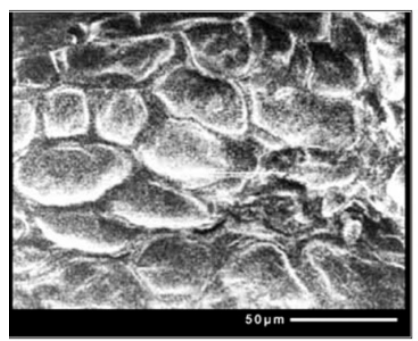

a
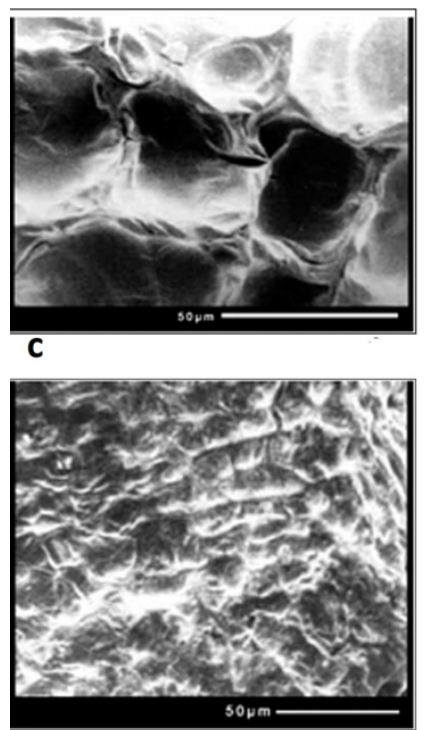

$\mathbf{e}$

Fig. 1: Scanning electron micrographs of seeds of Chirayat complex. a.Swertia chirayita; b.Swertia bimaculata; c. Swertia cordata; d. Swertia angustifolia; e. Swertia densifolia; f. Swertia paniculata.

\subsubsection{Swertia bimaculata Hook. $f$. \& thoms. ex Clarke.}

Seed circular, ovate, reddish brown, $0.61 \times 0.49 \mathrm{~mm}$ with shallowly sunken sides. Outer testa reticulate; cells polygonal, oriented irregularly; anticlinal walls curved, middle lamella conspicuous, forming trisectors at wall junctions; lumen smooth and shallowly concave (Fig.1b).

\subsubsection{Swertia angustifolia Ham. ex D. Don.}

Seed widely ovate, pale brown, 0.53 x $0.35 \mathrm{~mm}$ with shallowly sunken sides. Outer testa reticulate, cells polygonal; anticlinal walls straight; middle lamella inconspicuous; lumen smooth and deeply concave (Fig.1c).

\subsubsection{Swertia cordata (G.Don) Clarke.}

Seed elliptic, yellowish-brown, 0.74 x $0.54 \mathrm{~mm}$. Surface folded; folds arising from hilum with ridges and furrows. Outer testa reticulate, cells polygonal, oriented irregularly; anticlinal walls straight; middle lamella conspicuous, lumen rough and deeply concave (Fig.d)

\subsubsection{Swertia paniculata Wall.}

Seed oval widely elliptic, brownish-yellow, 0.41 x 0.32 $\mathrm{mm}$ with shallowly sunken sides. Outer testa reticulate, cells polygonal, oriented irregularly; anticlinal walls straight; middle lamella inconspicuous; lumen rough and shallow (Fig.1e) .

\subsubsection{Swertia densifolia (Griseb.) Kashyapa.}

Seed ovate, darkbrown, $0.46 \times 0.32 \mathrm{~mm}$. Outer testa reticulate, cells polygonal having honey comb like structure, anticlinal walls straight; middle lamella conspicuous; lumen smooth and deeply concave (Fig.1f).

\subsubsection{Swertia ciliata (G.Don)Burtt.}

Seed ovate-elliptic, compressed, yellow, 0.86 x $0.63 \mathrm{~mm}$ with shallowly sunken sides. Outer testa reticulate, cells irregularly polygonal; anticlinal walls straight; middle lamella inconspicuous; lumen rough and shallow (Fig. 2a).
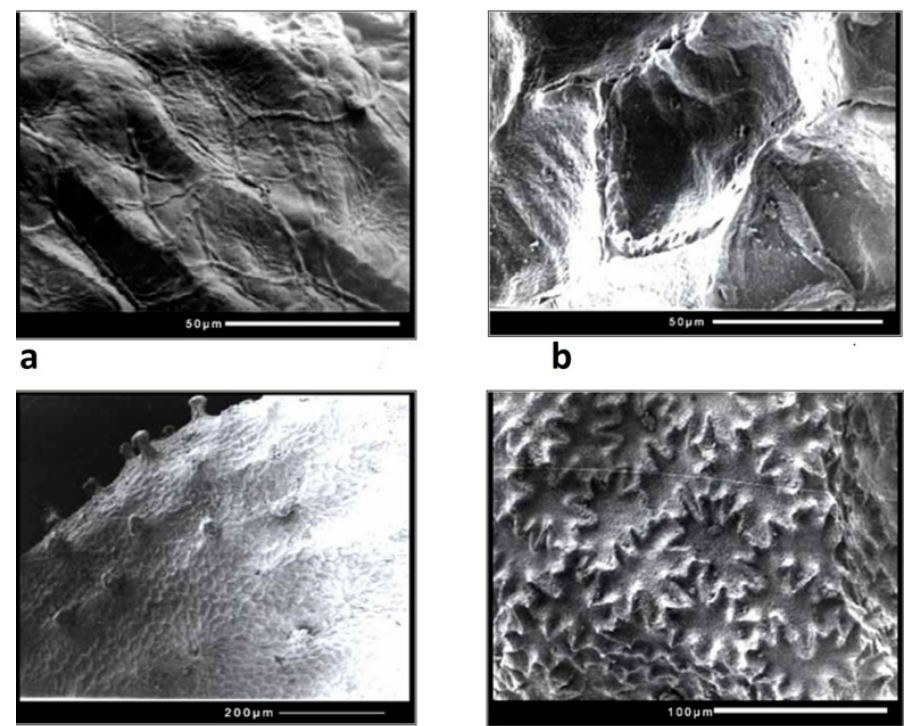

b

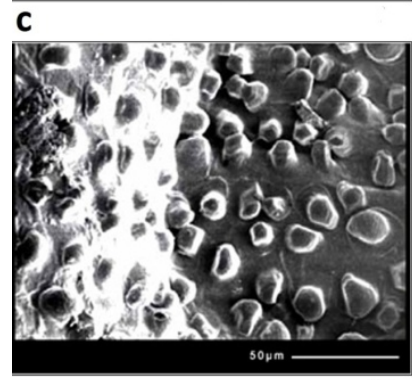

e

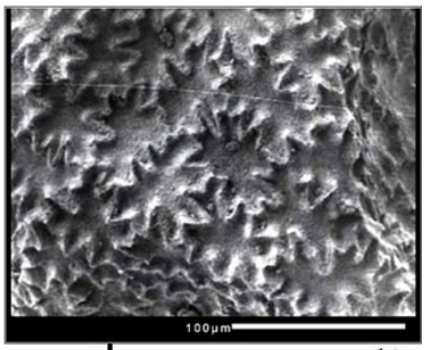

d

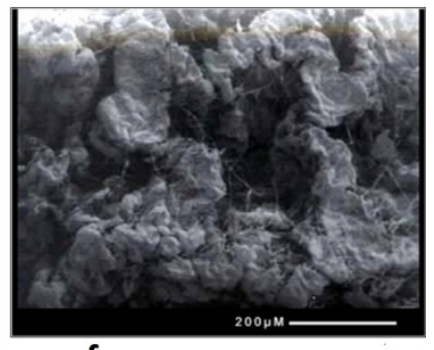

f

Fig. 2Scanning electron micrographs of seeds of Chirayat complex a. Swertia ciliata; b. Indoneesiella echioides; c. Peristrophe paniculata; d. Exacum tetragonum; e. Andrographis paniculata; f. Enicostema axillare. 


\subsubsection{Enicostema axillare (Lam.) Raynal.}

Seed spheroidal, globular, pale brown, $0.53 \times 0.45 \mathrm{~mm}$. Outer testa reticulate, cells polygonal, oriented irregularly; anticlinal walls straight with thick walled ridges, inner wall with fringes; lumen rough, shallowly concave (Fig. $2 b$ ) .

\subsubsection{Peristrophe paniculata (Forssk.) Brummitt.}

Seed flat circular, coffee black, $2.30 \times 2.15 \mathrm{~mm}$. Outer testa reticulate as well as tuberculated with large irregular branched ridges originated from hilum. Testa cells irregularly polygonal; anticlinal walls straight. Tubercles stalked, uniform, arranged irregularly; middle lamella inconspicuous; lumen rough and shallow (Fig. 2c).

\subsubsection{Exacum tetragonum Roxb.}

Seed rectangular, brick red, $0.28 \times 0.21 \mathrm{~mm}$. Outer testa reticulate, cell irregular, star shaped, oriented irregularly; anticlinal walls are wavy, undulations ' $V$ ' shaped; middle lamella inconspicuous; lumen broad, shallow and rough(Fig. 2d).

\subsubsection{Andrographis paniculata (Burm.f.) Wall. ex Nees.}

Seed rhombic, yellow, $1.75 \times 1.28 \mathrm{~mm}$, having some cracks and crevices. Outer testa is tuberculated. Tubercals quite prominent, variable in size and arranged in somewhat irregular fashion (Fig. 2e).

\subsubsection{Indoneesiella echioides (L.) Sreem.}

Seed ovate/ elliptic, black, $1.21 \times 0.80 \mathrm{~mm}$. Outer testa is folded; foldes join each other forming deep well like structure. Folds are wide (Fig. 2f).

From these SEM based observations, it is evident that species belonging to Chirayat group show diversity in seed characters in several respects. Color of the seed is variable between yellow, yellowish- brown to brown. It is distinctly brick red in Exacum tetragonum, red-brown in Swertia bimaculata, and black in Indoneesiella echioides and Perestrophe paniculata. Diversity in shapes is considerable but may be reduced to types like circular, oval elliptic and rectangular. Seeds are polymorphic in Exacum tetragonum. Seeds measured by length and breadth show significant variation. The seeds show cellular reticulate surface where the cells are polygonal (tetragonal, pentagonal hexagonal, elongated hexagonal or star shaped). Surface in some species is folded with discontinuous wall thickenings or it is covered with very small reticulum with scattered tubercles. Variations in surface structures have been used in present work for formulating a key for identification of different species. Overall these seed characters are very species specific and help in identification of the species in Chirayat complex.

\subsection{Proposed Key}

* Outer testa non-reticulate

$>$ Surface tuberculate, Seed colour yellow----------------------Indoneesiella echioides
Surface non-tuberculate, but folded, seed colour black-----Androgeaphis paniculata

$>$ Outer testa reticulate

$>$ Surface indistinctly reticulate

- Surface tuberculate, Seed black in colour Perstrophae paniculata

- Surface non-tuberculate,

$>$ Shape of seed rectangular, anticlinal wall wavy-------------------------Exacum tetragonum

1 Shape of seed ovate elliptic

$\checkmark$ Seed yellow in colour---------------------------Swertia ciliata

$\checkmark$ Seed brown in colour------------------Swertia paniculata

$>$ Surface distinctly reticulate

- Surface folded from hilum, anticlinal walls straight, lumen deep-------------Swertia cordata

- Surface non-folded

1. Middle lamella inconspicuous

$\checkmark$ Seed colour pale brown---------------Swertia angustifolia

1 Middle lamella conspicuous, Colour yellowish brown to dark brown

$\checkmark$ Anticlinal walls curved

$>$ Cells of reticulum shallow, Appear overlapped---------------------Swertia chirayita

$>$ Middle lamella form trisector at wall junctions---------------------Swertia bimaculata

$\checkmark$ Anticlinal walls straight

$>$ Testa cells having honey comb like structure, lumen deeply concave---------------Swertia densifolia

$>$ Inner wall of testa cells having fringes, forming folds on lumen-------------Enicostema axillare

\section{ACKNOWLEDGEMENT}

The authors are thankful to the Director and In-charge Botany Group ARI, Pune for providing facilities for this work. They are grateful to Mr. Dongre for help in SEM work. Special mention of help rendered from BSI -CNH, Howrah; Northern Circle, Dehra Dun; Sikkim circle and Western Circle, Pune for allowing to consult the herbarium for confirmation of species. Grant received from DBT for the project is gratefully acknowledged.

\section{REFERENCES}

1. Bahadur B., Venkateshwarlu K. and Rama Swamy N, SEM Studies of seeds in nine species of Petunia Juss (Solanaceae). Phytomorphology.1989; 39 (2, 3): 121-128.

2. Bahadur B., Bhasker K. V. and Forooqui S. M., The taxonomic significance of seed and seed coat ( LM \& SEM ) characters in six species of Nigella ( Ranunculaceae). Proc. Indian Acad. Sci. 1983; B 92: 429-435.

3. Das S., Mitra S. K. and Mukherjee K. K., SEM studies on seed coat of some species of Ipomoea (Convolvulaceae). Phytomorphology. 1995; 45 (1 \& 2): 113-125.

4. Jha S. S. and Pandey A. K., Seed coat structure in Melilotus (Fabaceae). Phytomorphology. 1989; 39 (2, 3): 221-229. 
5. Paul T. K. and Nayar M. P., A scanning electron microscope survey of seed surface morphology of some taxa of Malvaceae. Bull. Bot. Surv. India. 1987; 29 (1-4): 226-252.

6. Trivedi B. S., Bagchi G. D. and Bajpai Usha. Studies on seed and spermoderm structure of Bauhinia. Phytomorphology. 1980; 30: 1116.

7. Trivedi B. S, Bagchi G. D. and Bajpai Usha. SEM studies on the spermoderm of Sesbania Scop. (Leguminosae). Curr.Sci. 1978; 47: 599-600.

8. Garg S. Gentianaceae of N.W. Himalaya (Revision), (Today and Tomarrow Publisher, New Delhi. 1987.
9. Singh N.P., Lakshminarasimhan P. and Prasanna P. V. Flora of Maharashtra State Dicotyledones Vol 2. (BSI. Calcutta.). 2001.

\section{How to cite this article:}

Bharati Rajput, Vinaya Ghate. Authentication of "Chirayat" complex by high resolution seed morphology. J App Biol Biotech. 2014; 2 (06): 014-017. 